University of Warwick institutional repository: http://go.warwick.ac.uk/wrap This paper is made available online in accordance with publisher policies. Please scroll down to view the document itself. Please refer to the repository record for this item and our policy information available from the repository home page for further information.

To see the final version of this paper please visit the publisher's website. Access to the published version may require a subscription.

Author(s): Alec B.M. Moore

Article Title: Metazoan parasites of the lesser-spotted dogfish

Scyliorhinus canicula and their potential as stock discrimination tools

Year of publication: 2001

Link to published version: http://dx.doi.org/

10.1017/S0025315401004982

Publisher statement: None 


\title{
Metazoan parasites of the lesser-spotted dogfish Scyliorhinus canicula and their potential as stock discrimination tools
}

\author{
Alec B.M. Moore \\ Ecology and Epidemiology Group, Department of Biological Sciences, University of Warwick, \\ Coventry, CV4 7AL. E-mail: fleurandalec@hotmail.com. Present address: RSK Environment Ltd, \\ Spring Lodge, 172 Chester Road, Helsby, Cheshire, WA6 0AR
}

\begin{abstract}
The metazoan parasites of 101 lesser-spotted dogfish Scyliorhinus canicula from locations off the coast of England (Plymouth and the eastern Solent) and Wales (Cardigan Bay) were surveyed and assessed for their potential as stock discrimination tools.

A total of ten parasite species was found using a relatively rapid host examination technique suitable for non-parasitologists. On the basis of established criteria, larval anisakid nematodes and the copepod Lernaeopoda gale $i$ were selected as being potentially useful as stock discrimination tools. The monogeneans Leptocotyle minor and Hexabothrium appendiculatum may be suitable as markers following further investigation of their response to handling stress.
\end{abstract}

\section{INTRODUCTION}

There has been widespread and growing concern in recent years that certain chondrichthyan fish species are overexploited and, historically, targeted shark fisheries have usually collapsed. The current lack of knowledge on biological parameters is causing problems with effective management of sharks, rays and chimaeras (Camhi et al., 1998). Stock discrimination studies would assist in the assessment and management of these fisheries.

The lesser-spotted dogfish Scyliorhinus canicula (Linnaeus, 1758) is a small demersal catshark (Carcharhiniformes: Scyliorhinidae) that is abundant in the eastern Atlantic from Norway to West Africa, including the British Isles (Compagno, 1984). While not subject to targeted fisheries, it features prominently in commercial by-catches and recreational angling, and is of moderate commercial value for human consumption and industrial use (Compagno, 1984; Vas, 1995). Accurate landing statistics for S. canicula are not available, as it is usually combined with other small shark species; although it may be up to 10,000 tn annually (Vas, 1995). Furthermore, there are few studies relating to the population biology of S. canicula (D'Onghia et al., 1995; RodriguezCabello et al., 1998). Leah et al. (1991) analysed mercury levels in Irish Sea dogfish and, from these data, suggested that several major populations, which remained discrete during seasonal movements, were present within the area.

Parasites have been used successfully in stock discrimination studies of a variety of marine fish (e.g. Lester et al., 1988) and invertebrates (e.g. Thompson \& Margolis, 1987). Parasites can also provide information on diet, migrations and phylogeny (Williams et al., 1992).

The use of parasites as biological markers has a number of advantages. In comparison to conventional tagging programmes, where both capture and recapture are necessary to obtain data, a fish need only to be caught once, often by a routine sampling programme, for parasitological examination. This reduces time, cost and reliance on tag returns. In addition, as a natural part of the host's environment, parasite tags often eliminate the possibility of abnormal behaviour and/or selective mortality. They are also especially suitable for species that are small or delicate, for example some clupeids, deep water fish species or crustaceans that periodically shed tags on moulting (Williams et al., 1992).

Much of the work on parasites of elasmobranch fish has been unrelated to host biology. There have been some applied studies, reviewed by Caira (1990), including inferences made regarding host diet, predation, identification, phylogeny and ancient distributions. However, only one of these studies has looked at population biology. Watson \& Thorson (1976) provided supporting evidence for the marine migrations of the bull shark Carcharinus leucas and the sawfish Pristis perotteti from Central American fresh waters by analysis of parasite data. Further elasmobranch population studies based on parasitological data were highlighted by Williams et al. (1992) as an area of considerable potential, as the ecological and economic role of the host demands a better understanding of population biology. In addition, it was also stated that elasmobranchs carry a range of host-specific parasites that might serve as useful tags. The aim of the present study was to identify those species of parasite that will be suitable as markers. Lester (1990), Williams et al. (1992) and MacKenzie \& Abaunza (1998) list established criteria for the selection of tag species.

\section{MATERIALS AND METHODS}

A total of 101 whole, fresh Scyliorhinus canicula was caught from three locations: Plymouth, Cardigan Bay and the eastern Solent (Table 1). To minimize the possibility of infection parameters varying temporally all samples were obtained within a five-week period in June and July 1999. Fish were collected directly from skippers of commercial and recreational fishing vessels and stored in labelled 
Table 1. Details of Scyliorhinus canicula samples in chronological order.

\begin{tabular}{|c|c|c|c|c|c|c|}
\hline \multirow[b]{2}{*}{ Sample } & \multirow[b]{2}{*}{ Date } & \multirow[b]{2}{*}{ Position } & \multirow{2}{*}{$\begin{array}{c}\text { No. of fish } \\
\text { (males/females) }\end{array}$} & \multicolumn{3}{|c|}{ Length of fish (cm) } \\
\hline & & & & Range & Mean & SD \\
\hline Plymouth 1 & 08 June 1999 & $50^{\circ} 10^{\prime} \mathrm{N} 04^{\circ} 15^{\prime} \mathrm{W}$ & $35(15 / 20)$ & $38-65$ & 48.3 & 6.4 \\
\hline Plymouth 2 & 10 June 1999 & $50^{\circ} 15^{\prime} \mathrm{N} 04^{\circ} 10^{\prime} \mathrm{W}$ & $2(1 / 1)$ & $63-67$ & 65 & 2.8 \\
\hline Cardigan Bay 1 & 23 June 1999 & $52^{\circ} 16^{\prime} \mathrm{N} 04^{\circ} 16^{\prime} \mathrm{W}$ & $16(12 / 4)$ & $51-65$ & 55.5 & 3.8 \\
\hline Cardigan Bay 2 & 24 June 1999 & $52^{\circ} 34^{\prime} \mathrm{N} 04^{\circ} 21^{\prime} \mathrm{W}$ & $15(13 / 2)$ & $51-63$ & 56 & 3.2 \\
\hline Cardigan Bay 3 & 25 June 1999 & $52^{\circ} 20^{\prime} \mathrm{N} 04^{\circ} 14^{\prime} \mathrm{W}$ & $18(16 / 2)$ & $51-66$ & 56.8 & 4.0 \\
\hline Eastern Solent 1 & 14 July 1999 & $50^{\circ} 40^{\prime} \mathrm{N} 01^{\circ} 03^{\prime} \mathrm{W}$ & $3(1 / 2)$ & $52-62$ & 57.7 & 5.1 \\
\hline Eastern Solent 2 & 14 July 1999 & 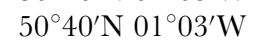 & $5(0 / 5)$ & $55-58$ & 56.2 & 1.3 \\
\hline Eastern Solent 3 & 15 July 1999 & $50^{\circ} 40^{\prime} \mathrm{N} 01^{\circ} 03^{\prime} \mathrm{W}$ & $2(0 / 2)$ & $55-57$ & 56 & 1.4 \\
\hline Eastern Solent 4 & 16 July 1999 & $50^{\circ} 40^{\prime} \mathrm{N} 01^{\circ} 03^{\prime} \mathrm{W}$ & $5(2 / 3)$ & $52-58$ & 55 & 2.4 \\
\hline
\end{tabular}

plastic bags, refrigerated and examined for parasites within $36 \mathrm{~h}$ of capture (usually within 24). Sex, weight (to the nearest $\mathrm{gm}$ ) and total length (to the nearest $\mathrm{cm}$ ) of all fish were recorded.

Examination for parasites commenced with a naked-eye search of all external surfaces, including the claspers and cloaca. Scrapings of all external surfaces were then taken with a broad scalpel (in the direction of the dermal denticles) prior to examination in seawater under a dissecting microscope. The nasal capsules and buccal cavity were then inspected prior to opening and/or removal of gills, whose surfaces were then inspected in seawater. The body cavity was opened with a ventral incision from the anus to the pectoral girdle, and the body wall, body cavity, and viscera were inspected. The wall of the stomach and spiral intestine was examined after these organs had been removed and opened by a longitudinal incision for inspection. All parasites were counted with the exception of the nematode Proleptus obtusus Dujardin 1845, which was often extremely abundant.

To aid identification, some platyhelminth specimens were flattened and fixed under coverslip pressure, and trypanorhynchs were placed in freshwater to evert their tentacles. Cestodes were fixed in Berland's fluid and all other parasites were fixed in either $10 \%$ formalin solution or $70 \%$ ethanol. All parasites were stored in $70 \%$ ethanol prior to microscopic identification. The encysted larval stage 3 nematodes Anisakis simplex (Rudolphi, 1809) Dujardin, 1845 and Pseudoterranova decipiens (Krabbe, 1878) Gibson \& Colin, 1982 were identified to species level, although these were pooled as larval anisakid nematodes for analysis. Prevalence and mean abundance (as defined by Bush et al., 1997) with standard deviation of the mean for each parasite taxon at each site were calculated. Voucher specimens of interest were deposited at the Natural History Museum, London.

Use of more detailed parasitological techniques and examination for microscopic organisms was deliberately excluded from this study, so as to develop a rapid, inexpensive methodology suitable for personnel with little or no parasitological training that could potentially be used in field conditions.

Following data collection, all species of parasite were assessed against the established criteria for suitability as tags. Broad comparisons of infection data were made in an attempt to discern patterns between sites or sexes; it was considered inappropriate to perform statistical tests, as sample sizes were often small and contained fish with large variations in length.

\section{RESULTS}

Sex and length of sampled Scyliorhinus canicula are shown in Table 1. A total of ten parasite species was found, and summary statistics of prevalence and abundance are displayed in Table 2. Nine specimens of the zoogonid digenean Diphterostomum betencourti (Monticelli, 1893) Odhner, 1911 (voucher specimen numbers 1999.9.29.7-15) recorded from a single eastern Solent fish are the first noted in British waters (Bray \& Moore, 2000). The pre-adult trypanorhynch Nybelinia lingualis (Cuvier, 1817) Dollfus, 1929 (numbers 1999.9.29.2-6) and larval anisakid nematode Pseudoterranova decipiens also represent possible new host records (R. Bray \& E. Harris, personal communication).

All samples of $S$. canicula were strongly dominated by a single sex, excepting Plymouth, which had 56\% females (Table 1). Most of the eastern Solent fish were female, while Cardigan Bay samples were dominated by males.

Larval anisakid nematodes, present in all samples, displayed large differences in infection. Prevalence in Cardigan Bay was far greater than elsewhere, and subsamples 1 to 3 here were remarkably similar (56.3, 53.3 and $50.0 \%$, respectively). The monogeneans Leptocotyle minor (Monticelli, 1888) Gallien, 1937 and Hexabothrium appendiculatum (Kuhn, 1829) von Nordmann, 1840 both showed marked differences in prevalence and mean abundance between samples; however, it was felt that these results may have been affected by handling stress between capture and examination of the host, especially for the ectoparasitic L. minor. Two copepod species were found: Albionella globosa (Leigh-Sharpe, 1918); and Lernaeopoda galei Krøyer, 1837, which only occurred on male Cardigan Bay fish.

Three uncommon species were found at one site only. The cestodes Crossobothrium longicolle (Molin, 1858) Euzet, 1959 (numbers 1999.9.29.16-17) and pre-adult $\mathcal{N}$. lingualis were found only at Plymouth, and D. betencourti was found only in the eastern Solent. In contrast, infection with the 
Table 2. Prevalence (P, \%) and abundance (A) of metazoan parasites in pooled samples of Scyliorhinus canicula.

\begin{tabular}{|c|c|c|c|c|c|c|c|c|c|c|}
\hline \multirow[b]{3}{*}{ Parasite } & \multirow{3}{*}{$\begin{array}{l}\text { Site of } \\
\text { infection }\end{array}$} & \multicolumn{3}{|c|}{ Plymouth $(\mathrm{N}=37)$} & \multicolumn{3}{|c|}{ Cardigan Bay $(\mathrm{N}=49)$} & \multicolumn{3}{|c|}{ Eastern Solent $(\mathrm{N}=15)$} \\
\hline & & \multicolumn{3}{|c|}{ A } & \multicolumn{3}{|c|}{ A } & \multicolumn{3}{|c|}{ A } \\
\hline & & $P$ & $\bar{x} \pm \mathrm{SD}$ & Range & $P$ & $\bar{x} \pm \mathrm{SD}$ & Range & $P$ & $\bar{x} \pm \mathrm{SD}$ & Range \\
\hline \multicolumn{11}{|l|}{ Monogenea } \\
\hline Leptocotyle minor & Skin & 97.3 & $3.6 \pm 3.4$ & $0-19$ & 38.8 & $1.3 \pm 2.4$ & $0-11$ & 0 & & \\
\hline $\begin{array}{l}\text { Hexabothrium } \\
\text { appendiculatum }\end{array}$ & Gill filaments & 16.2 & $0.9 \pm 3.1$ & $0-15$ & 4.1 & $0.1 \pm 0.4$ & $0-2$ & 0 & & \\
\hline \multicolumn{11}{|l|}{ Digenea } \\
\hline $\begin{array}{l}\text { Diphterostomum } \\
\text { betencourti }\end{array}$ & Spiral valve & 0 & & & 0 & & & 6.7 & $0.6 \pm 2.3$ & $0-9$ \\
\hline \multicolumn{11}{|l|}{ Cestoda } \\
\hline $\begin{array}{l}\text { Crossobothrium } \\
\text { longicolle }\end{array}$ & Spiral valve & 5.4 & $0.1 \pm 0.2$ & $0-1$ & 0 & & & 0 & & \\
\hline $\begin{array}{l}\text { Nybelinia } \\
\quad \text { lingualis }\end{array}$ & Stomach & 5.4 & $0.2 \pm 0.8$ & $0-5$ & 0 & & & 0 & & \\
\hline \multicolumn{11}{|l|}{ Nematoda } \\
\hline Anisakis simplex & $\begin{array}{l}\text { Wall of } \\
\text { stomach } \\
\text { (encysted) }\end{array}$ & 10.8 & $0.2 \pm 0.9$ & $0-5$ & 2.0 & $0.02 \pm 0$ & $10-1$ & 13.3 & $0.1 \pm 0.3$ & $0-1$ \\
\hline Proleptus obtusus & Stomach & 100 & & & 100 & & & 100 & & \\
\hline $\begin{array}{l}\text { Pseudoterranova } \\
\text { decipiens }\end{array}$ & $\begin{array}{l}\text { Wall of } \\
\text { stomach and } \\
\text { spiral valve, } \\
\text { soft tissues } \\
\text { (encysted) }\end{array}$ & 5.4 & $0.1 \pm 0.4$ & $0-2$ & 53.1 & $2.2 \pm 4.1$ & $0-17$ & 0 & & \\
\hline $\begin{array}{l}\text { Pooled larval } \\
\text { anisakids }\end{array}$ & & 16.2 & $0.3 \pm 0.9$ & $0-5$ & 53.1 & $2.2 \pm 4.1$ & $0-17$ & 13.3 & $0.1 \pm 0.3$ & $0-1$ \\
\hline \multicolumn{11}{|l|}{ Copepoda } \\
\hline Albionella globosa & Nasal capsule & 29.7 & $0.4 \pm 0.7$ & $0-2$ & 16.3 & $0.2 \pm 0.5$ & $0-2$ & 40.0 & $0.5 \pm 0.7$ & $0-2$ \\
\hline Lernaeopoda galei & $\begin{array}{l}\text { Claspers and } \\
\text { pelvic fin } \\
\text { insertion }\end{array}$ & 0 & & & 22.4 & $0.2 \pm 0.4$ & $0-1$ & 0 & & - \\
\hline
\end{tabular}

gastrointestinal nematode Proleptus obtusus was present in all fish examined.

These preliminary data appear to suggest that intensity of larval anisakid nematode infections is greater in longer, male fish. The infection in 30 (88.2\% of 34 infected fish) S. canicula consisted of one to five larvae. This included all female hosts, from which the maximum intensity recorded were three larvae. The remaining heavy infections of 12 to 17 larvae (found in four fish) were only found in larger $S$. canicula ( $>60 \mathrm{~cm}$ total length), which were all males.

\section{DISGUSSION}

\section{Nematodes}

Larval anisakid nematodes are probably the most promising stock discrimination parasites for Scyliorhinus canicula. Being long-lived, larval anisakids lying dormant for extended periods in their fish hosts tend to accumulate. Their abundance has been shown to generally increase with host size, for example in cod (Boily \& Marcogliese, 1995), a desirable characteristic for a parasite tag. In addition, infections showed strong geographical variations in both prevalence and mean abundance. The comparatively large size and often conspicuous nature of the worm (especially when encysted) allow for fairly rapid processing, provided identification is to family level. These combined factors have resulted in the group being the most commonly used in marine fish stock separation studies (Williams et al., 1992).

The results from the present study suggest that large male $S$. canicula should be used where possible for greater discriminatory power between potential host subpopulations when using intensity of larval anisakid nematode infection as a factor. The fact that Cardigan Bay sites 1 to 3 are so similar in prevalence of larval anisakid infection is interesting and may be preliminary evidence suggesting that these are from the same host subpopulation. However, homogeneity of infection does not necessarily imply host mixing.

\section{Copepods}

Lernaeopoda galei shows great potential as a tag species. As well as marked geographical variations in prevalence, it has an additional advantage in that infection data could 
easily be recorded, allowing opportunities for catch, release and recapture programmes. Both L. galei and Albionella globosa displayed favourable characteristics in terms of relatively large size, robust attachment and ease of detection and identification.

There is a lack of specific information on longevity and life history characteristics of elasmobranch copepods (Caira, 1990). As all copepod infections recorded in the present study were of either one or two animals, this may indicate a short-lived (i.e. life span $<1$ y) parasite that does not accumulate with host age. If this were the case host stock identification would not be possible, although useful inferences might still be made about seasonal host movements.

\section{Platyhelminths}

The data sets for both species of monogenean should take account of the considerable scope for loss or degeneration of these parasites through handling stress such as exposure to air. Fixing of hosts upon capture may counteract potential losses, although this would present constraints to a rapid and portable methodology. Despite this, it is felt that they are worthy of further investigation given their host (Llewellyn et al., 1984) and site specificity. Neither species is likely to be pathogenic (Kearn, 1965; Sproston, 1946) and the ectoparasitic Leptocotyle minor could also provide opportunities for infection data collection with catch-and-release of host.

\section{General comments}

Compared to the $100 \%$ prevalence in the present study, Proleptus obtusus infections in Scyliorhinus canicula from Galway Bay, Republic of Ireland (Henderson \& Dunne, 1998) were also very common (90.4\% prevalence). Larval anisakids, which at Galway only comprised Anisakis simplex, showed a very low prevalence of $5.5 \%$, which is markedly different from sites in the present study. This adds further support to the claim that infection with these parasites varies geographically, and are thus potentially useful as stock discrimination tools. The copepod Lernaeopoda galei was present in $27.4 \%$ of Galway fish, which again is markedly different to the absences of this potentially useful species recorded from Plymouth and the eastern Solent.

Scyliorhinus canicula is likely to be an important part of the coastal ecosystem and further work on its population biology would be useful, as well as a model for research on other shark species. A combination of both parasite and tagging data is a powerful complementary tool in evaluating the movements of fish (Lester et al., 1988; Lester, 1990). Scyliorhinus canicula seems well suited to such a study. Given the number of recreational captures (estimated at 5.39 per boat per day for the Republic of Ireland, 1978 to 1992; Vas, 1995), the potential exists for a large amount of data to be collected. In addition, experimental laboratory studies suggested that survival rate following T-bar anchor tagging in $S$. canicula was fairly high (Rodriguez-Cabello et al., 1998).

Although microscopic parasites such as trypanosomes were not examined for in this study, they do occur in S. canicula (Pulsford, 1984) and may prove a useful tool in further research, as they already have done in teleosts (Williams et al., 1992).

I am most grateful to Dr Ken MacKenzie (University of Aberdeen), Professor Robert Lester (University of Queensland) and Dr Aaron Henderson (National University of Ireland, Galway), who in addition to support throughout the work provided helpful comments on the manuscript; the constructive comments by anonymous referees are also appreciated. Dr Rod Bray and Eileen Harris (Natural History Museum, London) generously confirmed the identity of parasite species. Associate Professor Mike Bennett, Drs Leslie Chisholm, Tom Cribb and Ian Whittington (University of Queensland), Drs James Nokes and Graham Medley (University of Warwick), Professor Janine Caira (University of Connecticut) and Dr Graham Kearn (University of East Anglia) all provided valuable advice. For provision of laboratory facilities and/or assistance with obtaining fish, I am grateful to Drs Jack Harris and Annette Wrathmell (University of Plymouth), Dr Simon Creasey and Gareth Owen (University of Wales, Aberystwyth), Emu Environmental Ltd and Doug Herdson (National Marine Aquarium, Plymouth), as well as the skippers, crews and anglers who collected dogfish. This work was undertaken while the author was supported by a BBSRC studentship, and Warwick University assisted with fieldwork costs. Fleur Oliver provided continuous support.

\section{REFERENGES}

Boily, F. \& Marcogliese, J., 1995. Geographical variations in abundance of larval anisakine nematodes in Atlantic cod (Gadus morhua) and American plaice (Hippoglossoides platessoides) from the Gulf of St Lawrence. Canadian Fournal of Fisheries and Aquatic Sciences, 52, Supplement 1, 105-115.

Bray, R.A. \& Moore, A.B.M., 2000. The first record of the elasmobranch parasite Diphterostomum betencourti (Monticelli, 1893) (Digenea, Zoogonidae) in the coastal waters of southern England. Acta Parasitologica, 45, 299-302.

Bush, A.O., Lafferty, K.D., Lotz, J.M. \& Shostak, A.W., 1997. Parasitology meets ecology on its own terms: Margolis et al. revisited. Fournal of Parasitology, 83, 575-583.

Caira, J.N., 1990. Metazoan parasites as indicators of elasmobranch biology. In Elasmobranchs as living resources: advances in the biology, ecology, systematics, and the status of the fisheries (ed. H.L. Pratt Jr et al.), pp. 71-96. NOAA Technical Report, no. 90.

Camhi, M., Fowler, S., Musick, J., Brautigam, A. \& Fordham, S., 1998. Sharks and their relatives: ecology and conservation. Occasional Paper of the IUCN Species Survival Commission, no. 20.

Compagno, L.J.V., 1984. Sharks of the world: an annotated and illustrated catalogue of shark species known to date. Part 2, Carcharhiniformes. FAO Fisheries Synopses 125, 4, 251-655.

D’Onghia, G., Matarrese, A., Tursi, A. \& Sion, L., 1995. Observations on the depth distribution of the small-spotted catshark in the North Aegean Sea. Journal of Fish Biology, 47, 421-426.

Henderson, A.C. \& Dunne, J.J., 1998. The metazoan parasites of the lesser-spotted dogfish Scyliorhinus canicula (L.) from the Galway Bay area. Irish Naturalist's fournal, 26(3/4), 104-107.

Kearn, G.C., 1965. The biology of Leptocotyle minor, a skin parasite of the dogfish, Scyliorhinus canicula. Parasitology, 55, 473-480.

Leah, R., Evans, S. \& Johnson, M., 1991. Mercury in muscle tissue of lesser spotted dogfish (Scyliorhinus caniculus L.) from the north-east Irish Sea. The Science of the Total Environment, 108, 215-224.

Lester, R.J.G., 1990. Reappraisal of the use of parasites for fish stock identification. Australian Fournal of Marine and Freshwater Research, 41, 855-864.

Lester, R.J.G., Sewell, K.B., Barnes, A. \& Evans, K., 1988. Stock discrimination of orange roughy, Hoplostethus atlanticus, by parasite analysis. Marine Biology, 99, 137-143. 
Llewellyn, J., Green, J.E. \& Kearn, G.C., 1984. A check-list of monogenean (platyhelminth) parasites of Plymouth hosts. Fournal of the Marine Biological Association of the United Kingdom, 64, 881-887.

MacKenzie, K. \& Abaunza, P., 1998. Parasites as biological tags for stock discrimination of marine fish: a guide to procedures and methods. Fisheries Research, 38, $45-56$.

Pulsford, A., 1984. Preliminary studies on trypanosomes from the dogfish, Scyliorhinus canicula L. Journal of Fish Biology, 24, 671-682.

Rodriguez-Cabello, C., De La Gandara, F. \& Sanchez, F., 1998. Preliminary results on growth and movements of dogfish Scyliorhinus canicula (Linnaeus, 1758) in the Cantabrian Sea. Oceanologica Acta, 21, 363-370.

Sproston, N.G., 1946. A synopsis of the monogenetic tremaotodes. Transactions of the Zoological Society of London, 25, 185-600.
Thompson, A.B. \& Margolis, L., 1987. Determination of population discreteness in two species of shrimp, Pandalus jordani and Pandalopsis dispar, from coastal British Columbia using parasite tags and other population characteristics. Canadian Fournal of Fisheries and Aquatic Sciences, 44, 982-989.

Vas, P., 1995. The status and conservation of sharks in Britain. Aquatic Conservation: Marine and Freshwater Ecosystems, 5, 67-79.

Watson, D.E. \& Thorson, T.B., 1976. Helminths from elasmobranchs in Central American fresh waters. In Investigations of the ichthyofauna of Nicaraguan lakes (ed. T.B. Thorson), pp. 629640. Lincoln, Nebraska: School of Life Sciences, University of Nebraska.

Williams, H.H., MacKenzie, K. \& McCarthy, A.M., 1992. Parasites as biological indicators of the population biology, migrations, diet, and phylogenetics of fish. Reviews in Fish Biology and Fisheries, 2, 144-176.

Submitted 13 January 2001. Accepted 24 September 2001. 